Piotr Kubiak

Poznań

\title{
PRZEMIANY W OBRĘBIE NIEMIECKIEGO SYSTEMU PARTYJNEGO PO 2009 ROKU
}

Wybory do Bundestagu z 27 września 2009 r. stanowią bardzo ważną cezurę w dziejach niemieckiego systemu partyjnego. Utwierdziły one istnienie na szczeblu federacji systemu złożonego z pięciu partii przy równoczesnym osłabieniu dominującej pozycji obu wielkich Volksparteien (CDU/CSU i SPD). Po wyborach SPD po raz pierwszy od 1998 r. znalazła się w opozycji a do rządu po 11 latach powróciła FDP. Zmiana koalicji nie pozostała bez wpływu na dalsze losy partii. W dalszej części referatu podjęta zostanie próba odpowiedzi na najistotniejsze pytania badawcze: 1) co leżało u podstaw tak słabego wyniku obu Volksparteien, a w szczególności SPD?; 2) czy kierownictwa wielkich partii wyciągnęły wnioski z zaistniałej sytuacji?; 3) jak w oparciu o badania sondażowe i wyniki wyborów do parlamentów krajowych zmieniało się poparcie dla czołowych partii niemieckich w latach 2010-2012? Wstępem do dalszych rozważań będzie omówienie ewolucji i charakterystyka systemu partyjnego Republiki Federalnej Niemiec w latach 1949-2009.

\section{Ewolucja systemu partyjnego Republiki Federalnej Niemiec 1949-2009}

System polityczny Niemiec współczesnych uznawany jest za jeden z najlepiej funkcjonujących systemów demokratycznych na świecie. Filarem niemieckiej demokracji jest stabilny i zinstytucjonalizowany system partyjny z wyznaczoną konstytucyjnie dla partii politycznych rolą pośrednika „,w kształtowaniu woli politycznej narodu” (art. 21 Ustawy Zasadniczej). U źródeł trwałości ukształtowanego w latach pięćdziesiątych systemu partyjnego Republiki Federalnej Niemiec tkwią z jednej strony 
czynniki instytucjonalne (Ustawa Zasadnicza, ustawa o partiach politycznych z 1967 r. regulująca ich funkcjonowanie, ordynacja wyborcza z zapisaną 5\% klauzulą zaporową (Sperrklausel), z drugiej zaś strony przesłanki ekonomiczne i społeczne. Zachodnioniemiecki cud gospodarczy lat pięćdziesiątych i sześćdziesiątych XX w. przyczynił się w sposób istotny do wzmocnienia i utrwalenia zaufania społecznego do największych partii politycznych. Tym samym postawione zostały filary, na których do dnia dzisiejszego opiera się niemiecki system partyjny. Po krótkiej fazie formowania (lata 1949-1953) zachodnioniemiecki system partyjny przeszedł w fazę koncentracji (1953-do końca lat siedemdziesiątych). W fazie koncentracji, w której dominowały tendencje dośrodkowe wyodrębniły się trzy partie, które jako jedyne były w stanie przekroczyć w wyborach do Bundestagu obowiązująca na obszarze całej RFN 5\% klauzulę zaporową: CDU/CSU, SPD i FDP. W szczytowym momencie fazy koncentracji podczas wyborów z 1976 r. na CDU/CSU, SPD i FDP padło łącznie 99,1\% głosów (drugich), w tym na obie wielkie Volksparteien 91,2\%. Tym samym utrwalił się system dwóch wielkich partii i jednej połówki (FDP) przy czym w obliczu niemożności zdobycia większości miejsc w parlamencie przez żadną z obu Volksparteien wzrastało znaczenie FDP, która mogła decydować z kim chce tworzyć koalicję. Pojawienie się na niemieckiej scenie politycznej partii Zielonych zapoczątkowało fazę transformacji niemieckiego systemu partyjnego $\mathrm{w}$ latach osiemdziesiątych. Wejście partii Zielonych do Bundestagu w 1983 r. (5,6\% głosów) teoretycznie zwiększyło liczbę partii mogących wejść w skład koalicji rządowej, niemniej początkowo Zieloni byli traktowani z nieufnością przez pozostałe partie. Jednakże w obliczu długoletnich (1982-1998) rządów czarno-żółtej koalicji (CDU/CSU-FDP) następowało powolne zbliżenie na linii SPD-Zieloni, czego efektem było uformowanie się w latach dziewięćdziesiątych systemu dwublokowego: CDU/CSU-FDP oraz SPD-Zieloni ${ }^{1}$.

${ }^{1}$ Zagadnienie periodyzacji niemieckiego systemu partyjnego budziło zainteresowanie wielu badaczy. Ulrich von Aleman przyjął podział na następujące fazy: formowania (1945-1953), koncentracji (1953-1976), transformacji (1976-1994), stabilizacji (1994-2002) oraz na fazę płynną (po 2002). U. von Alemann, Das Parteiensystem der Bundesrepublik Deutschland, Bonn 2010 (wyd. 4), s. 46-50. Periodyzację Alemanna w polskiej nauce przyjął i nieco zmodyfikował Konstanty Adam Wojtaszczyk. Wyróżnił on następujące fazy: formowania (1945-1953), koncentracji (1953-1976), transformacji (1976-1990) oraz fazę tendencji dośrodkowych (1990-2003). K. A. Wojtaszczyk, Partie polityczne w niemieckiej debacie politologicznej i socjologicznej, [w:] red. K. A. Wojtaszczyk, Partie polityczne w Niemczech, Warszawa 2004, s. 10-13. Nieco inny podział przedstawił Oskar Niedermayer, który wyróżnił następujące fazy: formowania (1945-1953), konsolidacji lat pięćdziesiątych, dominacji trzech partii w latach sześćdziesiątych i siedemdziesiątych, pluralizacji lat osiemdziesiątych oraz fazę stopniowego kształtowania się systemu pięciopartyjnego po zjednoczeniu. O. Niedermayer, Die Entwicklung des bundesdeutschen Parteiensystems, [w:] red. F. Decker, 
Zjednoczenie Niemiec odznaczyło swoje piętno także na niemieckim systemie partyjnym. Zmiany dotyczyły przede wszystkim formatu, gdyż po zjednoczeniu zachowane zostały mechanizmy rządzące zachodnioniemieckim systemem partyjnym. Odradzające się we wschodnich Niemczech po upadku muru berlińskiego partie i ruchy demokratyczne w większości wypadków zostały już w 1990 r. wchłonięte przez ich ideowe odpowiedniki z zachodnich Niemiec (najdłużej, bo do maja 1993 r. trwał proces jednoczenia zachodnioniemieckich Zielonych z wschodnioniemieckim Sojuszem 90). Istotnym novum było pojawienie się postkomunistycznej Partii Demokratycznego Socjalizmu (Partei des Demokratischen Sozialismus, PDS), silnej na wschodzie, lecz w skali całych Niemiec balansującej na granicy progu wyborczego. PDS była ignorowana przez większość elit politycznych Niemiec, zwłaszcza na zachodzie. Jedynie SPD, ale tylko w krajach byłej NRD, była gotowa zawiązać z nią koalicję na szczeblu krajowym (Meklemburgia-Pomorze Przednie 1998-2002, Berlin po 2002 r.). Poprzez dołączenie balansującej na granicy progu wyborczego PDS i przy zachowaniu podziału na dwa bloki dotychczasowy system partyjny RFN złożony z czterech partii (CDU/CSU, SPD, FDP i Zielonych) wkroczył w latach 1990-2005 w fazę - jak to ujął Oskar Niedermayer - stopniowego kształtowania się systemu pięciopartyjnego (fluides Fünfparteiensystem). Dało się również zauważyć różnice w preferencjach wyborczych pomiędzy mieszkańcami starych i nowych krajów federacji. Wyniki wyborów do Bundestagu i parlamentów krajowych pokazują, że na obszarze byłej NRD ukształtował się de facto odrębny system partyjny z trzema wielkimi partiami (CDU, SPD, PDS) i dwoma mniejszymi (FDP, Zieloni). Na wschodzie Niemiec znaczne sukcesy odnosiły także partie skrajnie prawicowe zdobywając znaczne poparcie i mandaty we wschodnioniemieckich Landtagach (np. NPD w Saksonii w 2004 r., DVU w Brandenburgii)².

Istotne dla ewolucji niemieckiego systemu partyjnego okazały się przedterminowe wybory do Bundestagu z 18 września 2005 r. Poprzedziła

\footnotetext{
V. Neu, Handbuch der deutsche Parteien, Wiesbaden 2007, s. 120-131. Zupełnie inną koncepcję przyjął Ekhard Jesse, który dokonał podziału w oparciu o partie i koalicje będące u władzy. Wyróżnił on następujące fazy: początków partii politycznych i formowanie się systemu partyjnego (1945-1949), dominacji CDU (1949-1966), wielkiej koalicji CDU/ CSU-SPD (1966-1969), SPD jako dominującej w koalicji rządzącej (1969-1982), koalicji kierowanej przez chadecję (1982-1998) oraz (od 1998 r.) koalicji czerwono-zielonej. E. Jesse, Die Entwicklung des Parteiensystems und der Parteien in der Bundesrepublik Deutschland, [w:] red. E. Hüber, H. Oberreuter, Parteien und Wahlen in Deutschland, München 2003, s. 17-48.

${ }^{2}$ Więcej o wschodnioniemieckim systemie partyjnym: N. Werz, Parteien in den neuen Bundesländern seit 1990, [w:] red. E. Jesse, E. Klein, Das Parteienspektrum im wiedervereinigten Deutschland, Berlin 2007, s. 49-63; E. Bojenko-Izdebska, Przemiany w Niemczech Wschodnich 1989-201. Polityczne aspekty transformacji, Kraków 2011, s. 163-247.
} 
je seria niepowodzeń SPD w wyborach do parlamentów krajowych w latach 2003-2005 (SPD odnotowała spadek poparcia w jedenastu kolejnych wyborach krajowych) i utrata przez partie rządzącej koalicji SPD-Zieloni kanclerza Gerharda Schrödera większości w Bundesracie, co w połączeniu ze sporami wewnątrz SPD wokół forsowanego przez rząd programu reform Agenda 2010 zmusiło kanclerza do powzięcia decyzji o ponownym zwróceniu się do wyborców o wotum zaufania dla polityki rządu. Ostatecznie w dość kontrowersyjnych okolicznościach udało się doprowadzić do rozwiązania parlamentu i rozpisania nowych wyborów ${ }^{3}$. Wynik wyborów przyjęto w Niemczech z rozczarowaniem. Wprawdzie zwyciężyły partie chadeckie $(35,2 \%)$, jednak ich przewaga nad SPD okazała się minimalna (34,2\% poparcia). Na domiar złego żaden z bloków (CDU/CSU-FDP, SPD-Zieloni) nie zdołał uzyskać większości w Bundestagu. Swą pozycję wzmocniła liberalna FDP (9,8\% głosów, wzrost o 2,4p.p). Spory sukces odniosła za to dawna PDS, która wystartowała w wyborach jako Partia Lewicy w sojuszu z zachodnioniemiecką Alternatywą Wyborczą Praca i Sprawiedliwość Społeczna (WASG) rekrutującą się m.in. z przeciwników reform programu Agenda 2010. Dzięki temu Partia Lewicy uzyskała łącznie $8,7 \%$ (z tego blisko 5\% poparcia na zachodzie) co pozwoliło na zdystansowanie partii Zielonych (8,1\% poparcia). Tym samym po wyborach system partyjny Niemiec składał się z pięciu partii, a podział na dwa bloki stracił chwilowo rację bytu. Etap „stopniowego kształtowania się systemu pięciopartyjnego" dobiegł końca. Wejście tak silnej reprezentacji Partii Lewicy do Bundestagu w połączeniu $\mathrm{z}$ odmową pozostałych partii wejścia $\mathrm{z}$ nią w koalicję doprowadził do znacznych komplikacji przy tworzeniu rządu. Po długich negocjacjach powołano rząd wielkiej koalicji (CDU/ CSU-SPD) z kanclerz Angelą Merkel na czele 4 . Po raz drugi w dziejach Republiki Federalnej Niemiec obie Volksparteien utworzyły wspólny rząd.

\section{Wybory do Bundestagu z 27 września 2009 r. i ich następstwa}

W latach 2005-2007 współpraca wewnątrz wielkiej koalicji przebiegała bez większych konfliktów, niemniej SPD - chociaż posiadała tyle samo stanowisk w rządzie co partie chadeckie - była uważana za słabszego partnera $\mathrm{w}$ łonie koalicji. Sytuacja zmieniła się jesienią 2007 kiedy doszło do sporu wokół ustawowego wprowadzenia płacy minimalnej.

${ }^{3}$ K. Bachmann, P. Buras, S. Płóciennik, Republika bez gorsetu. Niemcy po wyborach 18 września 2005 roku, Wrocław 2005; P. Kubiak, Początki wielkiej koalicji w Niemczech (2005), Zeszyty Instytutu Zachodniego 49/2008, s. 11-15.

${ }_{4}$ Ibidem, s. 27-46. 
Partie chadeckie i rząd jako całość (w tym socjaldemokratyczny minister pracy Franz Münteferig) były temu przeciwne, lecz przewodniczący SPD Kurt Beck pod naciskiem lewego skrzydła partii opowiedział się za takim rozwiązaniem. Decyzja Becka wynikała z trudnego położenia w jakim znalazła się SPD. W czerwcu 2007 r. zakończył się proces łączenia dawnej PDS z WASG i na zjeździe w Berlinie powołano do życia nową partię Die Linke. Pojawienie się silnej konkurencji na lewicy wymusiło na kierownictwie SPD podjęcie aktywniejszych działań w celu utrzymania przy partii jej lewego skrzydła. W tej sytuacji K. Beck na zjeździe partii w Hamburgu (26-28 października 2007 r.) opowiedział się za lansowanym przez związki zawodowe wprowadzeniem płacy minimalnej co spotkało się z krytyką prawego skrzydła partii obawiającego się załamania programu Agenda 2010 i konfliktu w łonie koalicji. Podczas zjazdu K. Beck przeforsował swój zamiar, a dwa tygodnie później F. Müntefering zrezygnował $\mathrm{z}$ zajmowanych stanowisk $\mathrm{w}$ rządzie oraz partii i wycofał się z polityki. Inicjatywa K. Becka przyniosła tylko chwilowy sukces (wynik wyborów w Hesji z 20 stycznia 2008 r.). Wiosną i latem 2008 r. poparcie dla SPD w sondażach malało, część dawnego elektoratu socjaldemokratów wsparła teraz Die Linke, partia była skłócona, a jej przewodniczący nie panował nad sytuacją. W tej sytuacji we wrześniu 2008 r. K. Beck został zmuszony do rezygnacji z kierowania partią a jego miejsce zajął tandem: Frank-Walter Steinmeier (kandydat SPD na kanclerza) oraz powracający do polityki F. Müntefering (przewodniczący partii). SPD wkraczała w rok wyborczy osłabiona i skłócona ${ }^{5}$, do tego kryzys na rynkach finansowych powodował, że współpraca $\mathrm{z}$ chadekami w ramach wielkiej koalicji układała się coraz gorzej. Tymczasem notowania partii opozycyjnych w sondażach przedwyborczych rosły, co nie wróżyło dobrze dla partii rządzących. Czerwcowe wybory do Parlamentu Europejskiego stanowiły poważne ostrzeżenie dla SPD, która uzyskała zaledwie 20,8\% głosów.

Wybory do Bundestagu z 27 września 2009 r. zakończyły się niepomyślnie dla partii wielkiej koalicji. O ile straty partii chadeckich były niewielkie (-1,4p.p.), o tyle SPD poniosła druzgocącą klęskę uzyskując zaledwie $23 \%$ głosów i tracąc aż 11,2p.p. poparcia (co w praktyce oznaczało utratę blisko 1/3 głosów). Był to najgorszy wynik uzyskany przez SPD

${ }^{5}$ Więcej o sporach wewnątrz SPD: P. Kubiak, W cieniu wielkiej koalicji. SPD w latach 2005-2009 (w druku), referat wygłoszony w maju 2010 r. podczas I Zjazdu Niemcoznawców we Wrocławiu.; M. Reinhardt, Parteiflügelkämpfe seit der Bundestagswahl 2002. Kampf um die Macht in der SPD, [w:] red. H. Geiling, Die Krise der SPD. Autoritäre oder Prinzipatorische Demokratie, Münster 2009, s. 77-98; J. Raschke, Zerfallsphase des Schröder-Zyklus. Die SPD 2005-2009, [w:] red. C. Egle, R. Zohlnhöfer, Die zweite Große Koalition. Einer Bilanz der Regierung Merkel 2005-2009, Wiesbaden 201, s. 69-97. 
w wyborach do Bundestagu od początku istnienia Republiki Federalnej Niemiec. Beneficjentami niepowodzenia wielkich partii okazały się partie średnie, będące w opozycji wobec rządu wielkiej koalicji Angeli Merkel: FDP uzyskała 14,6\% głosów (wzrost o 4,8p.p.), Die Linke 11,9\% (+3,2p.p.), Zieloni 10,7\% (+2,6p.p.). Każda z trzech partii uzyskała najlepszy wynik w swej historii. Die Linke i Zieloni przejęli część niezadowolonego z polityki partii elektoratu SPD, podobnie FDP, którą poparło część elektoratu partii chadeckich. Warto odnotować, że startująca po raz pierwszy w wyborach do Bundestagu Partia Piratów uzyskała 2\% poparcia, dzięki czemu stała się najsilniejszą partią spośród tych, które nie dostały się do parlamentu. Pomimo drobnych strat partiom chadeckim udało się wraz ze wzmocnioną FDP utworzyć rząd cieszący się poparciem większości Bundestagu.

Tabela 1. Zestawienie wyników wyborów do Bundestagu z 18 września 2005 r. i 27 września 2009 r. (głosy drugie)

\begin{tabular}{|l|c|c|c|c|c|}
\hline \multirow{2}{*}{ Partia } & \multicolumn{2}{|c|}{ Wybory z 2005 r. } & \multicolumn{2}{c|}{ Wybory z 2009 r. } & Różnica głosów \\
\cline { 2 - 5 } & \% głosów & mandaty & \% głosów & mandaty & (p.p.) \\
\hline CDU/CSU & 35,2 & 226 & 33,8 & 239 & $-1,4$ \\
\hline SPD & 34,2 & 222 & 23,0 & 146 & $-11,2$ \\
\hline FDP & 9,8 & 61 & 14,6 & 93 & $+4,8$ \\
\hline Die Linke & 8,7 & 54 & 11,9 & 76 & $+3,2$ \\
\hline Zieloni & 8,1 & 51 & 10,7 & 68 & $+2,6$ \\
\hline Pozostałe & 4,0 & - & 6,0 & - & $+2,0$ \\
\hline Eącznie & 100,00 & 614 & 100,00 & 622 & \\
\hline
\end{tabular}

${ }^{*}$ W 2005 r. jako Partia Lewicy, w 2009 r. jako Die Linke.

Źródło: Opracowanie własne na podstawie wyników wyborów.

Dla ewolucji niemieckiego systemu partyjnego wybory z 27 września 2009 r. miały niezwykle istotne znaczenie. Po raz drugi z rzędu w Bundestagu znalazło się pięć partii politycznych co utwierdziło istnienie w RFN systemu pięciu partii. Po raz pierwszy partii Die Linke (spadkobiercy dawnej PDS) udało się przekroczyć granicę progu wyborczego również w zachodniej części Niemiec (8,3\% na zachodzie, 23,6\% na wschodzie), co zdaniem Ulricha Eitha pozwala uznać wybory z roku 2009 za „przejście” do nowej epoki w dziejach niemieckiego systemu partyjnego podobnie jak to miało miejsce w wypadku wyborów z 1983 r. i partii Zielonych ${ }^{6}$. Drugim istotnym powodem dla którego można traktować wybory

${ }^{6}$ U. Eith, Volksparteien unter Druck. Koalitionspositionen, Integrationsfähigkeit und Kommunikationsstrategien nach der Übergangswahl 2009, [w:] red. K-R. Korte, Die Bundestagswahl 
z 2009 r. jako przełomowe $\mathrm{w}$ dziejach niemieckiego systemu partyjnego jest podważenie po raz pierwszy w dziejach RFN dominacji dwóch wielkich Volksparteien. Zdaniem Oskara Niedermayera dominacja dwóch partii (Zweiparteiendominanz) opierała się na posiadaniu przez nie 2/3 mandatów w Bundestagu, przy czym każda z nich musiała mieć więcej niż 1/4 mandatów i być co najmniej dwukrotnie silniejszą od następnej partii. W Bundestagu XVII kadencji (od 2009 r.) CDU/CSU i SPD posiadają łącznie 385 spośród 622 mandatów (2/3 to 414 posłów), SPD ma jedynie 146 mandatów (25\% to 156), a trzecia z kolei partia (FDP) deleguje 93 posłów. Tym samym obie Volsparteien utraciły większość 2/3 mandatów w Bundestagu niezbędną do samodzielnego podjęcie decyzji o zmianie konstytucji (przy czym konieczna jest zgoda 2/3 Bundesratu) ${ }^{7}$.

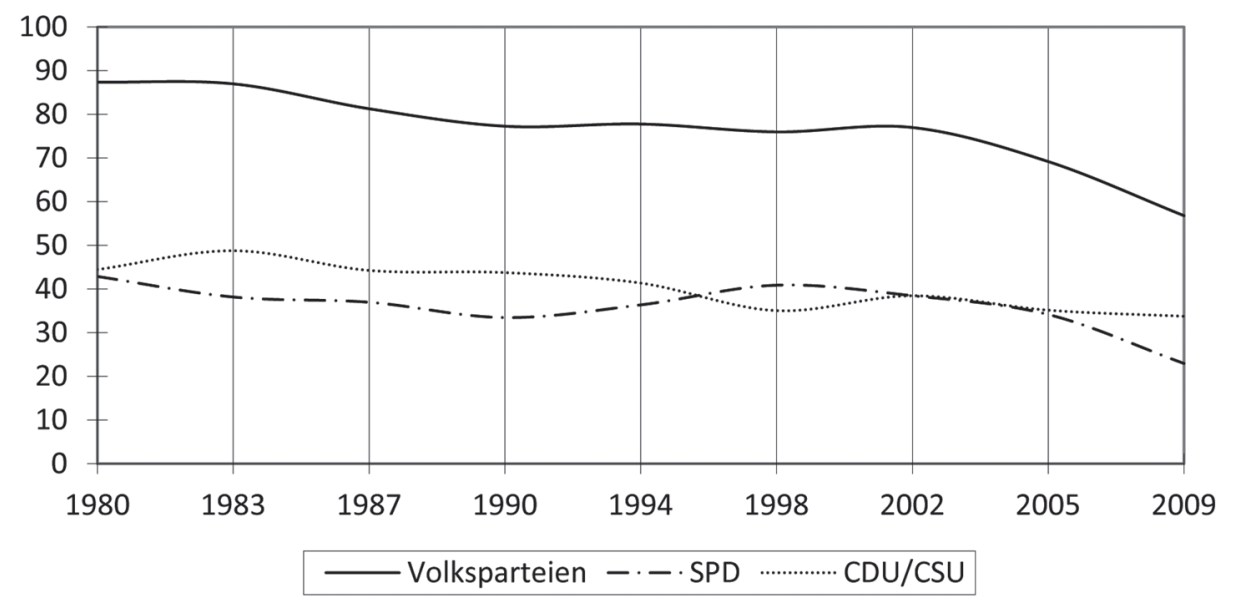

Wykres 1. Procentowe poparcie dla obu Volksparteien (SPD i CDU/CSU) w wyborach do Bundestagu w latach 1980-2009

Źródło: Opracowanie własne w oparciu o wyniki wyborów. Zob. P. Cichocki, P. Kubiak, M. Nowosielski, Dynamika niemieckiej opinii publicznej (styczeń-luty 2011), „Biuletyn Instytutu Zachodniego" nr 50/2011, s. 3.

Fatalny wynik obu Volsparteien (w szczególności SPD) stał się impulsem dla odrodzenia się debaty o końcu Volksparteien w dotychczasowej formie, w jakiej ukształtowały się one w latach pięćdziesiątych i sześćdziesiątych

2009. Analysen der Wahl-, Parteien-, Kommunikations- und Regierungsforschung, Wiesbaden 2010, s. 117.

7 O. Niedermayer, Die Erosion der Volksparteien, „Zeitschrift für Politik” 3/2010, s. 265272; Idem, Das deutsche Parteiensystem nach der Bundestagswahl 2009 [w:] red. O. Niedermayer, Die Parteien nach der Bundestagswahl 2009, Wiesbaden 2011, s. 9. 
XX wieku. Wtedy „SPD oraz CDU/CSU przekształciły się w nowoczesne partie masowe, dysponujące efektywnym aparatem partyjnym, profesjonalnymi funkcjonariuszami i rozbudowaną strukturą organizacyjną. Co istotne, partie te odeszły od swego wcześniejszego ściśle klasowego lub konfesyjnego charakteru, starając się zintegrować różne grupy społeczne i wyznaniowe. $W$ efekcie obie partie coraz bardziej upodabniały się do siebie pod względem programowym i społecznym, co równocześnie doprowadziło do większej zdolności zawierania przez nie koalicji z innymi partiami"s. Jednak w obliczu konkurencji ze strony innych partii po 1980 r. stopniowo traciły popularność.

W nauce niemieckiej występuje cały szereg definicji wyjaśniających specyficzne dla niemieckich wielkich partii pojęcie Volksparteien ${ }^{9}$. Zdaniem Petera Lösche partia chcąca być zaliczana do grona Volksparteien powinna reprezentować następujące cechy: 1) nie może być ograniczona do jednej klasy i grupy społecznej (wyznaniowej), lecz integrować w sobie różne grupy społeczne przy zachowaniu specyficznego profilu socjalnego; 2) powinna mieć poparcie co najmniej 35\% (według innych autorów 30\%, $25 \%$, a nawet $20 \%{ }^{10}$ ) wyborców, a liczba członków partii nie powinna być mniejsza niż 1\% uprawnionych do głosowania; 3) Volkspartei powinna mieć odpowiednie zaplecze kadrowe gotowe w każdej chwili do objęcia władzy oraz posiadać zdolność do zawierania koalicji z innymi ugrupowaniami; 4) jądro partii powinno skupiać się wokół działaczy z określonych środowisk - w wypadku SPD można mówić o środowisku robotniczym (związkowym), w wypadku CDU (a zwłaszcza CSU) o środowiskach katolickich ${ }^{11}$. Według P. Lösche za tezą o kryzysie (a nawet końcu) Volksparteien przemawiają następujące argumenty: spadające poparcie i stopniowa utrata wpływów politycznych, spadek liczby członków przede wszystkim w wyniku wymierania, którego nie rekompensuje dopływ młodych kadr (starzenie się partii) oraz rozpad więzi spajających tradycyjne zaplecze obu Volksparteien (w wypadku SPD środowiska robotnicze, związki zawodowe związane z wielkim przemysłem; środowiska katolickie w wypad-

${ }^{8}$ P. Kubiak, Stabilność niemieckiego systemu partyjnego: widoki na przyszłość Volksparteien, [w:] P. Cichocki, P. Kubiak, M. Nowosielski, Dynamika niemieckiej opinii publicznej (styczeń-luty 2011), „Biuletyn Instytutu Zachodniego” nr 50/2011, s. 3. http://www.iz.poznan. pl/news/261_nr\%2050.\%20biuletynIZ_KAS1.pdf (dostęp: 20 grudnia 2012).

${ }^{9}$ Pojęcie Volspartei (dosłownie: partia ludowa) w zależności od kontekstu jest różnie tłumaczone na język polski. W odniesieniu do omawianego tutaj typu partii najlepszym rozwiązaniem wydaje się użycie terminu „partia ogólnospołeczna”, który uwypukla aspekt integracyjny obu wielkich partii niemieckich.

${ }^{10} \mathrm{H}$. Oberreuter, Parteiensystem im Wandel. Haben die Volksparteien Zukunft?, [w:] red. V. Kronenberg, T. Mayer, Volksparteien: Erfolgsmodel für die Zukunft?, Freiburg im Breisgau 2009, s. 45, 46.

11 P. Lösche, Ende der Volksparteien, „Aus Politik und Zeitgeschichte” 51/2009, s. 6-8. 
ku CDU/CSU) ${ }^{12}$. Inni badacze (jak Tilman Mayer i Heinrich Oberreuter) dostrzegali przed Volksparteien szansę na odzyskanie przynajmniej części wpływów poprzez znalezienie odpowiedzi na najważniejsze wyzwania cywilizacyjne jak globalizacja, rozwój demograficzny i rozwój nauki oraz w oparciu o niewykorzystany do końca przez wielkie partie ich zdolność integracyjną mogącą przyciągnąć rzesze wyborców (głównie wśród przedstawicieli klasy średniej, młodzieży oraz mniejszości narodowych i grup etnicznych) ${ }^{13}$. Kolejne miesiące miały pokazać, czy Volksparteien (a w szczególności SPD) będą w stanie odzyskać zaufanie wyborców.

Fatalny dla SPD wynik wyborów z 2009 r. otworzył wewnątrzpartyjną debatę na temat przyczyn klęski i wyciągnięcia odpowiednich wniosków na przyszłość. Socjaldemokraci musieli przyzwyczaić się do nowej sytuacji: po 11 latach znowu znaleźli się w opozycji. Wśród przyczyn niepowodzenia można wymienić społeczne koszty reform programu Agenda 2010, spory wewnątrzpartyjne pomiędzy prawicą widzącą SPD jako lewicową partię środka a partyjną lewicą koncentrującą się na kwestiach socjalnych. Nie bez znaczenia była narastająca konkurencja ze strony die Linke. Kosztowny dla SPD okazał się udział w rządzie wielkiej koalicji w roli słabszego partnera. Polityczną odpowiedzialność za klęskę wyborczą partii wziął na siebie F. Müntefering, który ustąpił ze stanowiska przewodniczącego partii. W trakcie zjazdu partii (13-15 listopada w Dreźnie) wybrano nowe kierownictwo partii. Na czele SPD stanął reprezentujący partyjne centrum Sigmar Gabriel, wśród czterech wiceprzewodniczących znaleźli się przedstawiciele obu skrzydeł partii, sekretarzem partii została przedstawicielka partyjnej lewicy Andrea Nahles, a na czele frakcji parlamentarnej SPD stanął F-W. Steinmeier. Na zjeździe wyciszono spory wewnątrzpartyjne, a SPD znajdująca się w opozycji do rządu CDU/CSU-FDP mogła o wiele łatwiej rywalizować z Die Linke o utracony w latach 2007-2009 elektorat.

\section{Przełom 2010/2011: Zieloni u szczytu popularności, liberałowie na dnie}

W latach 2010-2012 nastroje wśród niemieckich partii politycznych zmieniały się wielokrotnie. Miernikiem popularności partii politycznych w okresie pomiędzy wyborami do Bundestagu były badania sondażowe

${ }^{12}$ Ibidem, s. 7-9. W dość sceptycznym tonie o przyszłości Volksparteien pisali C. Eith i O. Niedermayer.

${ }^{13}$ H. Oberreuter, op. cit., s. 54-56; T. Mayer, Von der Mitte her denken. Das bürgerliche Lager und das Potential der Volksparteien, [w:] red. V. Kronenberg, T. Mayer, Volksparteien: Erfolgsmodel für die Zukunft?, Freiburg im Breisgau 2009, s. 12-25. 
(w dalszej części analizowany będą sondaże Politbarometru realizowane przez Forschungsgruppe Wahlen dla telewizji ZDF) oraz wybory do parlamentów krajowych. W latach 2010-2012 w Niemczech zorganizowano jedenaście wyborów do Landtagów dziesięciu krajach federacji (w Nadrenii Północnej-Westfalii wybory odbyły się dwukrotnie: w 2010 i 2012 r.). Wybory krajowe śledzone są z wielką uwagą przez obserwatorów niemieckiej sceny politycznej, ponieważ są ważnym testem popularności dla partii politycznych. Wybory krajowe mają także pośredni wpływ na kształt reprezentacji krajów delegowanych do Bundesratu ${ }^{14}$. Niemniej poparcie dla partii politycznych może znacznie się różnić na poziomie federalnym i krajowym, co może wynikać z tradycji, innej ordynacji wyborczej, statusu społecznego, sytuacji gospodarczej czy też struktury wyznaniowej danego kraju federacji, a także większej konkurencji ze strony ugrupowań regionalnych. W tym kontekście ważne jest porównanie wyników osiąganych przez partie w następujących po sobie wyborach. Na szczeblu krajowym niemieckie partie polityczne są znacznie bardziej elastyczne w kwestii zawierania koalicji aniżeli na szczeblu federalnym.

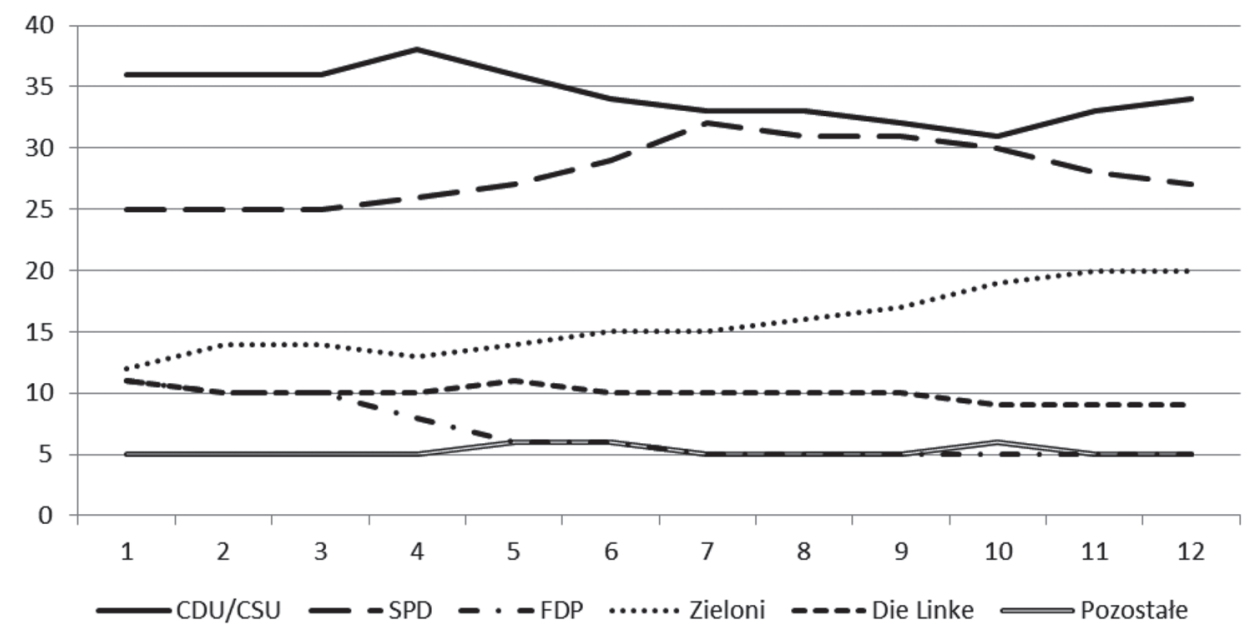

Wykres 2. Sondażowe poparcie dla niemieckich partii politycznych w $2010 \mathrm{r}$.

(w procentach)

Źródło: Forschungsgruppe Wahlen, Politbarometer

${ }^{14}$ Szerzej o zależnościach pomiędzy federalizmem i systemem partyjnym: M. Witkowska, Partie polityczne w krajach zwiazkowych Republiki Federalnej Niemiec, Warszawa 2003; Parteien und Parteiensysteme in den deutschen Ländern, red. U. Jun, M. Haas, O. Niedermayer, Wiesbaden 2008. 
W pierwszych miesiącach $2010 \mathrm{r}$. badania sondażowe nie wykazały większych zmian poparcia $\mathrm{w}$ obrębie niemieckich partii politycznych. Najistotniejszy był spadek poparcia (z 11\% w styczniu do $8 \%$ w maju) dla FDP oraz niewielki wzrost notowań SPD i Zielonych. Najpoważniejszą próbą sił dla niemieckich partii politycznych były zaplanowane na 9 maja 2010 r. wybory do parlamentu krajowego Nadrenii Północnej-Westfalii. W porównaniu do wyborów z 2005 r. obie Volksparteien poniosły znaczne straty (rządząca w koalicji z liberałami CDU aż o 8,2p.p.) uzyskując niemal identyczne wyniki: CDU 34,6\%, SPD 34,5\%. Znaczny wzrost poparcia odnotowali Zieloni uzyskując 12,1\% głosów, jednak nie wystarczyło to, aby koalicja SPD-Zieloni miała większość w Landtagu (zabrakło jednego mandatu). Do parlamentu dostały się również FDP (6,7\% poparcia) oraz Die Linke (5,6\% poparcia). Przekroczenie przez Die Linke progu wyborczego uniemożliwiło zdobycie większości mandatów przez koalicję SPD-Zieloni. Po długich negocjacjach powołano rząd mniejszościowy SPD-Zielony Hannelore Kraft tolerowany przez Die Linke. CDU i FDP znalazły się w opozycji. Utrata władzy w Nadrenii Północnej-Westfalii przez koalicję CDU-FDP była ciosem dla rządu federalnego, który tym samym utracił większość w Bundesracie.

W drugiej połowie $2010 \mathrm{r}$. gwałtownie rosło poparcie dla partii Zielonych, którą w sondażach popierało nawet $20 \%$ respondentów. U źródeł popularności partii ekologów leżały dwie sprawy: protesty społeczne przeciwko rozbudowie dworca w Stuttgarcie (projekt Stuttgart 21) i zaangażowanie partii po stronie protestujących „wściekłych obywateli” (Wutbürger) oraz wszczęta przez rząd debata na temat możliwości przedłużenia funkcjonowania elektrowni atomowych, co spotkało się ze sprzeciwem Zielonych. Nagły wzrost poparcia dla Zielonych wywołał spore zamieszanie wśród obserwatorów niemieckiej sceny politycznej. W mediach sugerowano nawet, że Zieloni wkrótce staną się trzecią Volkspartei i już pukają do elitarnego „klubu Volksparteien"15. Były to jednak zapowiedzi przedwczesne, a sama partia Zielonych nie była przygotowana na taki awans ze względu na zbyt małą liczbę członków (w tym czasie partia liczyła ok. 53000 członków, mniej nawet niż FDP i Die Linke) oraz luźną strukturę organizacyjną. Bilans poparcia dla niemieckich partii politycznych w roku $2010 \mathrm{w}$ badaniach sondażowych przedstawiał się następująco: CDU/CSU spadek o 2p.p. z 36\% poparcia w styczniu do $34 \%$ w grudniu, SPD wzrost o 2p.p. z $25 \%$ do $27 \%$. Zieloni wzrost o 8p.p. z $12 \%$ do $20 \%$, FDP spadek o 6p.p. z 11\% na 5\%, Die Linke spadek o 2p.p. z 11\% na $9 \%$.

${ }^{15}$ L. Probst, Bündnis90/Die Grünen auf dem Weg zur "Volkspartei”? Eine Analyse der Entwicklung der Grünen seit der Bundestagswahl 2005, [w:] Die Parteien nach der Bundestagswahl 2009, (red.) O. Niedermayer, Wiesbaden 2011, s. 150-154. 
W roku 2011 odbyło się w Niemczech aż siedem wyborów do parlamentów krajowych. Uwerturę stanowiły przedterminowe wybory w Hamburgu (20.02.2011 r.), gdzie w listopadzie 2010 r. rozpadła się rządząca od 2008 r. koalicja CDU-Zieloni. Wybory przeprowadzono według nowej ordynacji wyborczej dającą wyborcom większą możliwość wyboru konkretnego kandydata kosztem głosów na listę partyjną, a kandydatom niezależnym dającą większe szanse wyboru. Bezdyskusyjne zwycięstwo odniosła SPD uzyskując 48,4\% głosów (wzrost o 14,3p.p. w stosunku do wyborów z 2008 r.) co przełożyło się na zdobycie przez socjaldemokratów większości miejsc (62 spośród 121) w hamburskim Zgromadzeniu Obywatelskim (Bürgerschaft). Dzięki temu socjaldemokraci mogli samodzielnie utworzyć rząd (Senat) na którego czele stanął Olaf Scholz. Tym razem dotkliwe straty poniosła CDU, na którą głosowało 21,9\% wyborców (spadek aż o 20,9p.p.), Zieloni zwiększyli swe poparcie, Die Linke utrzymała swą pozycję, za to znaczny wzrost poparcia odnotowała FDP dzięki czemu liberałowie ponownie zasiedli się $\mathrm{w}$ Zgromadzeniu Obywatelskim ${ }^{16}$. Jednakże z racji specyfiki hamburskiej sceny politycznej, gdzie poparcie dla partii politycznych potrafiło zmieniać się w kolejnych wyborach w sposób drastyczny, wynik ten nie miał aż trak wielkiego wpływu na sytuację na sytuację w pozostałych częściach Niemiec.

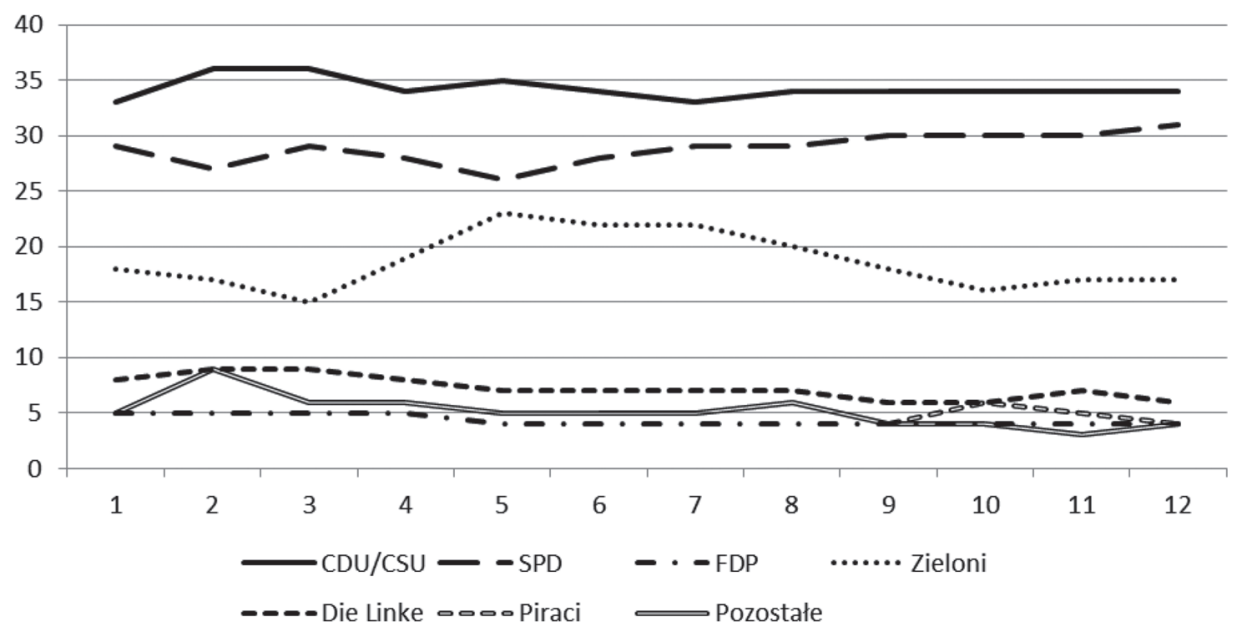

Wykres 3. Poparcie dla niemieckich partii politycznych w oparciu o sondaż Politbarometru w 2011 r. (w procentach)

Źródło: Forschungsgruppe Wahlen, Politbarometer

${ }^{16}$ Więcej o wyborach w Hamburgu: P. Horst, Das neue Hamburger Wahlrecht auf dem Prüfstand: kontraproduktiv, aber schwer reformierbar, "Zeitschrift für Parlamentsfragen" nr 4/2011, s. 707-724. 
Na drugą połowę marca zaplanowano wybory aż w trzech krajach: Saksonii-Anhalt (20.03), Nadrenii-Palatynacie (27.03) i Badenii-Wirtembergii (27.03). W czasie kampanii wyborczej ważnym punktem debaty publicznej była kwestia przyszłości energetyki atomowej. W momencie najgorętszej dyskusji wokół nowelizacji przez rząd federalny tzw. ustawy atomowej z 2002 r., która umożliwiała dłuższe funkcjonowanie elektrowni atomowych (w tym starszego typu wybudowanych przed 1980 r.) doszło 11 marca w Japonii do trzęsienia ziemi i tsunami, które doprowadziło do wycieku radioaktywnego w elektrowni atomowej Fukushima. Katastrofa w Japonii miała istotny wpływ na przebieg debaty nad przyszłością energetyki atomowej w Niemczech. Pod naciskiem opinii publicznej i partii opozycyjnych (w szczególności Zielonych) rząd federalny ogłosił 14 marca trzymiesięczne moratorium na wykonanie ustawy, co oznacza tymczasowe wygaszenie siedmiu najstarszych elektrowni w celu sprawdzenia ich bezpieczeństwa. Zdaniem opozycji decyzja rządu miała podłoże polityczna i była podyktowana uspokojeniem wyborców przed wyborami krajowymi. Kwestia energetyki atomowej nie miała jednak większego wpływu na wyniki wyborów w Saksonii-Anhalt, gdzie zachowano status quo i u władzy pozostała wielka koalicja CDU-SPD. Inaczej przedstawiała się sytuacja w południowo-zachodnich Niemczech. W Nadrenii-Palatynacie Zieloni wyraźnie wzmocnili swoją pozycję poprawiając swe notowania niemal trzykrotnie w stosunku do wyborów z 2006 r. - wzrost o 10,8p.p. z 4,6\% do 15,4\% - i weszli do Landtagu w Moguncji od razu jako trzecia siła. Dotkliwe straty poniosła tutaj SPD, która rządziła tutaj samodzielnie, a liberałowie nie osiągnęli progu wyborczego i znaleźli się poza parlamentem. W tej sytuacji powstał zatem rząd koalicyjny SPD-Zieloni ${ }^{17}$. Uwaga większości obserwatorów niemieckiej sceny politycznej zwrócona była jednak przede wszystkim na Badenię-Wirtembergię, gdzie działały dwie elektrownie atomowe starszego typu wybudowane jeszcze przed 1980 rokiem, a jesienią 2010 r. doszło do burzliwych protestów w Stuttgarcie przeciwko podjętej bez konsultacji społecznych decyzji władz o przebudowie dworca kolejowego. To właśnie te dwie sprawy mobilizowały partię Zielonych i jej elektorat. Wybory przyniosły ogromny sukces partii Zielonych, która uzyskując 24,2\% głosów (wzrost o 12,5p.p. w stosunku do wyborów w 2006 r.) stała się drugą siłą w Badenii-Wirtembergii. Pozostałe partie reprezentowane dotychczas w Landtagu poniosły straty, a rządząca koalicja CDU-FDP utraciła większość. W tej sytuacji powołano rząd koalicyjny

${ }^{17}$ H. Giothe, Die rheinland-pfälzische Landtagswahl vom 27. März 2011. Dosierte Machtwechsel in Mainz, "Zeitschrift für Parlamentsfragen”, nr 4/2011, s. 764-783. 
Zieloni-SPD. Na czele rządu krajowego po raz pierwszy w dziejach stanął polityk partii Zielonych - Winfried Kretschmann ${ }^{18}$.

Bilans marcowych wyborów do parlamentów krajowych okazał się zdecydowanie niekorzystny dla rządzącej w Niemczech koalicji chadecko-liberalnej. CDU udało się wprawdzie uzyskać większe poparcie w Nadrenii-Palatynacie, co pozwoliło niemal zrównać się z SPD, lecz partii pozostała tutaj nadal w opozycji. W Saksonii-Anhalt zachowano status quo, za to utrata władzy w Badenii-Wirtenbergii była bolesna. Jeszcze gorzej przedstawiała się sytuacja FDP. Liberałowie utracili miejsce w parlamentach krajowych Saksonii-Anhalt i Nadrenii-Palatynatu, a w Badenii-Wirtembergii, kraju gdzie tradycje liberalne były bardzo silne, utracili połowę głosów i z wielkim trudem udało się FDP przekroczyć 5\% poparcia i wejść do parlamentu. Niepowodzenia w marcowych wyborach do parlamentów krajowych wywołały polityczną burzę w FDP. W opinii wielu działaczy za taki stan odpowiedzialny był Guido Westerwelle, przewodniczący partii, a zarazem wicekanclerz i minister spraw zagranicznych. G. Westerwelle, który zyskał popularność jako lider partii opozycyjnej, nie radził sobie $\mathrm{w}$ roli ministra spraw zagranicznych i był najgorzej ocenianym ministrem w rządzie A. Merkel. Cierpiała na tym i FDP, która w sondażach balansowała na granicy progu wyborczego. Zdaniem wielu obserwatorów FDP stała się w rządzie uległym dodatkiem dla partii chadeckich. Jeszcze większa krytyka spadła na G. Westerwellego po tym jak 17 marca Niemcy wstrzymały się od głosu podczas głosowania Rady Bezpieczeństwa ONZ nad rezolucją nr 1973 w sprawie Libii. W obliczu narastającej krytyki G. Westerwelle ogłosił na początku kwietnia decyzję o swojej rezygnacji z kandydowania na stanowisko przewodniczącego partii na zbliżającym się kongresie w Rostoku (13 maja). Na stanowisko przewodniczącego prezydium partii wyznaczyło Philippa Röslera, federalnego ministra zdrowia, a delegaci na kongres udzielili mu wotum zaufania (95\% głosów). P. Rösler objął teraz resort gospodarki i stanowisko wicekanclerza, G. Westerwelle pozostał na stanowisku ministra spraw zagranicznych. Dokonano zmian we władzach partii, gdzie ważne stanowiska objęli młodzi politycy. Głównym zadaniem stojącym przed nowym kierownictwem partii była odbudowa zaufania dla FDP. Pierwsze niepowodzenie przyszło bardzo szybko. W wyborach krajowych w Bremie (22.05.2011 r.) FDP uzyskała zaledwie 2,4\% głosów i nie weszła do miejscowego parlamentu. Wybory w Bremie przyniosły sukces rządzącej wcześniej koalicji SPD-Zieloni, która pozostała u władzy ${ }^{19}$.

${ }_{18}$ P. Cichocki, P. Kubiak, M. Nowosielski, Dynamika niemieckiej opinii publicznej (marzec-kwiecień 2011), „Biuletyn Instytutu Zachodniego” 53/2011, s. 2-7. http://www.iz.poznan.pl/news/296_296_nr\%2053.\%20BiuletynIZ_KAS2.pdf (dostęp: 20 grudnia 2012 r.)

${ }^{19}$ L. Probst, Die Bürgerschaftswahl In Bremen vom 22. Mai 2011. Triumph für Rot-Grün, „Abwahl” der Opposition, ,Zeitschrift für Parlamentsfragen” nr 4/2011, s. 804-819. 


\section{Jesień 2011: Partia Piratów wkracza na scenę}

Latem i wczesną jesienią 2011 r. dało się zauważyć w sondażach powolny spadek popularności partii Zielonych. Spadek poparcia dla Zielonych wynikał po części z wyczerpania się kluczowych dla partii tematów (zejście debaty atomowej na drugi plan). 4 września odbyły się wybory w Meklemburgii-Pomorzu Przednim, które nie przyniosły większych zmian. U władzy pozostała wielka koalicja SPD-CDU przy czym wzmocnieniu uległa pozycja SPD (wzrost poparcia o 5,4p.p.). Także tutaj partia Zielonych odnotowała widoczny wzrost poparcia, za to FDP poniosła dotkliwe straty i znalazła się poza parlamentem ${ }^{20}$. Dwa tygodnie później odbyły się wybory w Berlinie, których rezultat zaskoczył wielu obserwatorów niemieckiej sceny politycznej. W wyborach zgodnie $\mathrm{z}$ oczekiwaniami zwyciężyła SPD (28,3\% głosów), przed CDU (23,4\%), partią Zielonych (17,6\%) i Die Linke (11,7\%). Rządzące wcześniej w Berlinie SPD i Die Linke poniosły minimalne straty, CDU i partia Zielonych zanotowały wzrost poparcia; FDP poniosła największe straty i nie znalazła się w parlamencie. Przed wyborami wiele wskazywało na to, że w Berlinie powstanie rząd koalicji SPD-Zieloni, jednak w wyniku sporu o koszty dokończenia budowy węzła autostrady A100 rozmowy koalicyjne obu partii spełzły na niczym. W tej sytuacji SPD porozumiała się z CDU powołując rząd wielkiej koalicji ${ }^{21}$. Prawdziwą sensację wywołał jednak wynik jaki osiągnęła Partia Piratów. Piraci uzyskali w Berlinie 8,9\% głosów i po raz pierwszy weszli do parlamentu krajowego. Sukces Partii Piratów był o tyle niespodziewany, że wcześniej nie byli oni wyróżniani w sondażach (Politbarometer ujął ich dopiero w październiku z poparciem na poziomie 4\%). Partia Piratów była tworem stosunkowo młodym. Została założona 10 września $2006 \mathrm{r}$. w Berlinie i powstała pod wpływem szwedzkiej Partii Piratów. Nowa partia utożsamia się z międzynarodowym ruchem dążącym do większej swobody w Internecie, postuluje ograniczenie możliwości monitorowania przez policję i służby specjalne poczynań obywateli w sieci oraz opowiada się za wzmocnieniem ochrony danych osobowych. Tym samym Partia Piratów stała się swego rodzaju produktem rewolucji informatycznej. Piraci nie deklarowali się dotychczas ani jako partia lewicowa, ani jako prawicowa, znacznie bliżej im do partii antysystemowej. Początkowo Partia

${ }^{20}$ M. Koschkar, S. Schoon, Die Mecklenburg-vorpommersche Landtagswahl vom 4. September 2011: Bestätigung der Großen Koalition mit sozialdemokratischen Zugewinn, "Zeitschrift für Parlamentsfragen" nr 1/2012, s. 3-18.

${ }^{21}$ O. Niedermayer, Die Berliner Abgeordnetenhaus vom 18. September 2011: Grün war nur die Hoffnung, die Realität ist rot-schwarz, "Zeitschrift für Parlamentsfragen" nr 1/2012, s. $18-34$. 
Piratów cieszyła się śladowym poparciem, ale już w trakcie wyborów do Bundestagu (27.09.2009 r.) na Piratów głosowało 2\% wyborców. W kolejnych miesiącach nastąpił lawinowy wzrost liczby członków - z około 1000 na początku 2009 r., poprzez 9000 w czasie wyborów do Bundestagu, aż po $12000 \mathrm{w}$ połowie roku $2010^{22}$. Partia Piratów uczestniczyła we wszystkich wyborach do parlamentów krajowych w 2011 r. uzyskując w większości wypadków wyniki na poziomie ok. $2 \%$. W ostatnich miesiącach 2011 r. odnotowane w sondażach poparcie dla Partii Piratów utrzymywało się w okolicach progu wyborczego - 4-6\%. Na początku 2012 r. dzięki debacie wokół wprowadzenia ACTA i masowym protestom przeciwko jej ratyfikowaniu poparcie dla PP jeszcze wzrosło. Interesujące, że pojawienie się Partii Piratów wiązało się ze spadkiem wpływów partii Zielonych. Można zgodzić się z tezą, że dla części dotychczasowego elektoratu Zielonych to właśnie Partia Piratów stała się prawdziwą partią antysystemową. Bilans roku 2011 dla niemieckich partii wyrażany w sondażach Politbarometru przedstawiał się następująco: CDU - wzrost o 1p.p. (33\% poparcia w styczniu, 34\% w grudniu), SPD - wzrost o 2p.p. (z 29 do 31\%), Zieloni - spadek o 1p.p. (z 18\% na 17\%), FDP - spadek o 1p.p. (z 5\% na 4\%), Die Linke - spadek o 2p.p. (z $8 \%$ na $6 \%$ ).

\section{Rok 2012: stabilizacja}

Rok 2012 rozpoczął się w Niemczech od serii nieoczekiwanych wydarzeń. Pierwsze miesiące roku upłynęły Niemcom na roztrząsaniu kulisów afery związanej z osobą prezydenta Christiana Wulffa, przyczyn jego ustąpienia, kryzysu instytucji prezydenta i wyborze jego następcy. Nie brakowało także protestów przeciwko ACTA. Niejako w tle tych wydarzeń w dwóch krajach federacji doszło do rozwiązania parlamentów i rozpisania przedterminowych wyborów, a w Szlezwiku Holsztynie w związku z nieprecyzyjną ordynacją wyborczą przeprowadzenie nowych wyborów nakazał krajowy Trybunał Konstytucyjny. W styczniu 2012 r. w Kraju Saary ogłoszono rozpad koalicji CDU-FDP-Zieloni (tzw. koalicji jamajskiej) a nowe wybory wyznaczono na dzień 25 marca. Intencją stojącej za całą akcją premier rządu krajowego Annegret Kramp-Karrenbauer (CDU) było powołanie w Kraju Saary rządu wielkiej koalicji opartego na stabilnej większości w miejscowym Landtagu. Wybory z 25 marca 2012 r. wzmocniły pozycję zarówno CDU jak i SPD, jednocześnie spadło poparcie dla

${ }^{22}$ Szerzej o początkach Partii Piratów: O Niedermayer, Erfolgsbedingungen neuer Parteien in Parteiensystem am Beispiel der Piratenpartei Deutschland, "Zeitschrift für Parlamentsfragen" nr 4/201, s. 838-854 (zwłaszcza s. 843-854; zestawienie liczby członków s. 846). 
niezwykle wpływowej tutaj Die Linke. Partia Zielonych, która miała tutaj słabą pozycję, poniosła niewielkie straty (-0,9p.p.) z trudem przekraczając granicę progu wyborczego. Zieloni zdystansowani zostali przez Partię Piratów, która mimo kłopotów organizacyjnych uzyskała 7,4\% głosów. Druzgocącą klęskę ponieśli liberałowie, których poparło zaledwie 1,2\% głosujących czego następstwem była utrata miejsca w parlamencie krajowym. Zgodnie z intencją A. Kramp-Karrenbauer po wyborach powołano rząd wielkiej koalicji CDU-SPD, którego objęła przewodnictwo.

U źródeł przedterminowych wyborów parlamentarnych w Szlezwiku-Holsztynie tkwiła niedoskonała ordynacja wyborcza, która w 2009 r. pozwoliła na uzyskanie większości mandatów koalicji CDU-FDP. Ordynację (a właściwie sposób przydzielania mandatów nadliczbowych) partie opozycyjne zaskarżyły do krajowego Trybunału Konstytucyjnego, który wydał korzystny dla nich wyrok. Wyznaczono zatem nowe wybory na dzień 6 maja 2012 r. Tym razem partie koalicji CDU-FDP nie uzyskały większości mandatów, chociaż CDU niemal utrzymała swoje dotychczasowe poparcie, a FDP pomimo sporych strat uzyskała najlepszy wynik $(8,2 \%)$ w wyborach krajowych od czasu wejścia do rządu federalnego w 2009 r. Także tutaj Partia Piratów uzyskała obiecujący wynik - 8,2\%. 12 czerwca powołany został nowy rząd koalicji SPD - Zieloni - SSW (SSW - partia mniejszości duńskiej) Torstena Albiga cieszący się poparciem 35 spośród 69 posłów Landtagu w Kilonii.

Wybory w Nadrenii Północnej-Westfalii z 9 maja 2010 r. przyniosły tylko połowiczny sukces koalicji SPD-Zieloni. Partiom lewicowym udało się zdystansować rządzącą tutaj w latach 2005-2010 koalicję CDU-FDP, jednak nie udało się utworzyć rządu większościowego. Powołano za to rząd mniejszościowy SPD-Zieloni tolerowany przez Die Linke. W praktyce oznaczało to, że pozycja rządu $\mathrm{H}$. Kraft była chwiejna, uzależniona od postawy Die Linke. W tym kształcie rząd przetrwał półtora roku. Kością niezgody okazał się rządowy projekt budżetu, który nie uzyskał akceptacji Landtagu. W tej sytuacji 14 marca 2012 r. przegłosowany został wniosek o samorozwiązanie parlamentu w Düsseldorfie. Termin nowych wyborów wyznaczono na 13 maja. Wybory zakończyły się zwycięstwem SPD (39,1\% głosów), która wraz z partią Zielonych (11,3\%) mogła powołać rząd większościowy, co też nastąpiło. Dotkliwe straty poniosła CDU (na chadeków głosowało zaledwie 26,3\% wyborców, aż o 8,3p.p. mniej niż w 2010 r.). Nieoczekiwanie wzrost poparcia $\mathrm{w}$ stosunku do poprzednich wyborów odnotowała FDP, na którą głosowało 8,6\% wyborców, a na Partię Piratów padło 7,8\% głosów. Die Linke uzyskała zaledwie 2,5\% poparcia i nie weszła do parlamentu.

Sondaże przedwyborcze pokazują, że w drugiej połowie 2012 r. poparcie dla większości partii politycznych ustabilizowało się na dotychczasowym 
poziomie. Dało się odnotować niewielki wzrost poparcia w wypadku CDU/CSU. Drobny spadek poparcia odnotowała za to Partia Piratów, która boryka się ze sporami wewnętrznymi i kłopotami organizacyjnymi. W ostatnim sondażu roku 2012 poparcie dla partii wyglądało następująco: CDU/CSU - 40\%, SPD - 30\%, Zieloni - 13\%, Die Linke 7\%, FDP - 4\%, Partia Piratów - 3\%. Gdyby wyniki wyborów do Bundestagu pokryły się z ostatnim sondażem, to w Bundestagu XVIII kadencji znaleźliby się przedstawiciele 4 partii - CDU/CSU, SPD, Zieloni i Die Linke. Zabrakłoby miejsca dla FDP. Przy takim rozkładzie głosów i określonym potencjale koalicyjnym poszczególnych partii niełatwe byłoby utworzenie koalicji mającej większość w Bundestagu, za wyjątkiem wielkiej koalicji. Dlatego ewentualne wejście FDP do parlamentu może mieć fundamentalne znaczenie dla kształtu przyszłej koalicji.

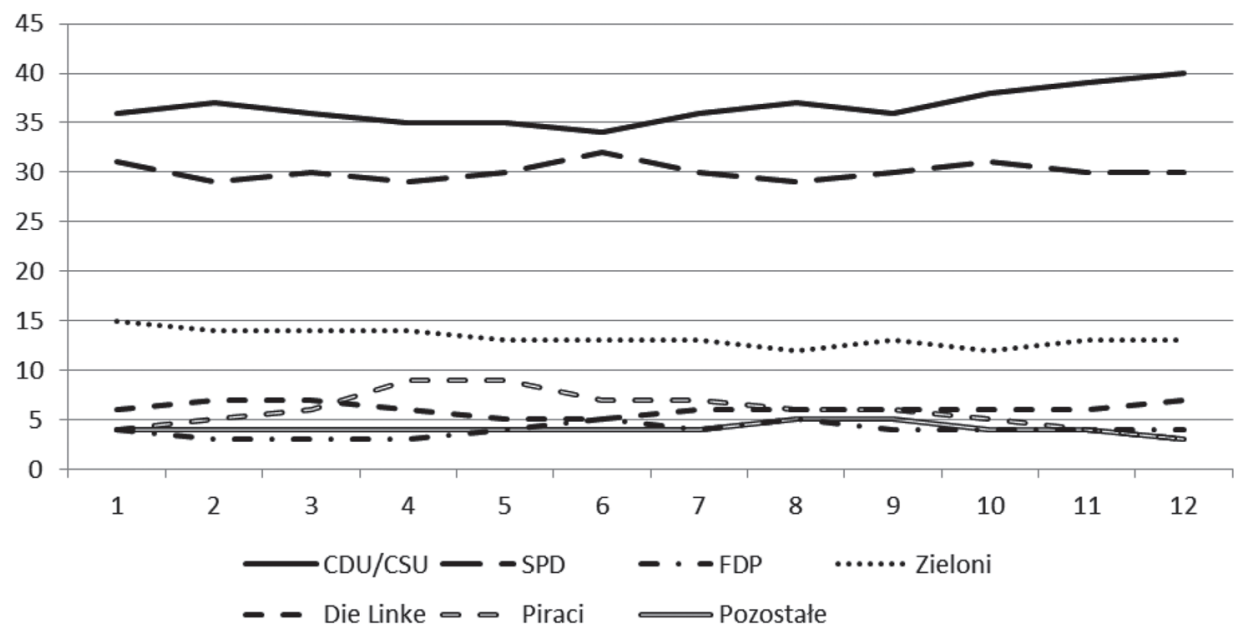

Wykres 4. Poparcie dla niemieckich partii politycznych w 2012 r. w oparciu o sondaż Politbarometru (w procentach)

Źródło: Forschungsgruppe Wahlen, Politbarometer

\section{Zakończenie}

Wybory do Bundestagu z 27 września 2009 r. otworzyły przed niemieckimi partiami politycznymi nowe perspektywy. Utwierdzony został system pięciu partii przy jednoczesnym spadku poparcia dla obu Volksparteien (dotkliwym w wypadku SPD). Tym samym zachwiana została dominacja obu wielkich partii, a sam system partyjny wydawał się ewoluować 
w kierunku większej pluralizacji. Wybory do parlamentów krajowych i sondaże przedwyborcze z lat 2010-2012 pokazały jednak, że niemiecki system partyjny cały czas ewoluuje, jednak trudno określić dokładne kierunki tej ewolucji. Można jednak dostrzec kilka ważnych przesłanek:

1) Odzyskanie dominującej pozycji przez obie Volksparteien - zarówno CDU/CSU jak i SPD bardzo szybko uporały się z kryzysem zaufania jaki miał miejsce u schyłku rządów wielkiej koalicji. Interesujące, że CDU wysokie notowania uzyskała jako partia rządząca (w przeciwieństwie do partnera koalicyjnego, który pogrążony jest w kryzysie), zaś SPD odzyskała siły jako partia opozycyjna. W ostatnich sondażach obie partie cieszą się poparciem ok. $70 \%$ respondentów.

2) Zieloni jako trzecia siła polityczna - $w$ dobie kryzysu FDP i osłabienia Die Linke partia Zielonych wysforowała się zdecydowanie na trzecie miejsce. Wprawdzie w 2012 r. nie cieszyła się taką popularnością jak w pierwszej połowie $2011 \mathrm{r}$. jednak jej pozycja jest stabilna.

3) Kryzys FDP - w ciągu dwóch lat liberalna FDP stoczyła się z trzeciej siły politycznej w partię rozpaczliwie walczącą o przekroczenie bariery $5 \%$. Liberałowie ponoszą koszty udziału w rządzie w roli zdecydowanie słabszego partnera, rezygnacji z własnych propozycji i polityki ustępstw na rzecz silniejszego partnera. Liberałom doskwiera kryzys przywództwa; zarówno G. Westerwelle jak i P. Rösler nie potrafili zaradzić problemom partii. Przyzwoite wyniki uzyskane przez FDP w wyborach krajowych w Szlezwiku-Holsztynie i Nadrenii Północnej-Westfalii pozwalają mieć nadzieję, że wrócą lepsze czasy dla liberałów. Jeśli FDP w najbliższych wyborach przekroczy prób wyborczy, to istnieją spore szanse, że znajdzie się w rządzie (z CDU).

4) Osłabienie pozycji Die Linke - Die Linke profitowała w latach 20082009 przede wszystkim dzięki problemom SPD. Tymczasem po przejściu socjaldemokratów do opozycji znaczna część ich dawnych sympatyków (głównie z Niemiec Zachodnich) powróciła na łono dawnej partii. Die Linke nadal jest silna w Niemczech Wschodnich, jednak na Zachodzie jej poparcie wyraźnie zmalało co odzwierciedlają wyniki wyborów do parlamentów krajowych.

5) Partia Piratów i jej przyszłość - Wydaje się, że po spektakularnym wejściu na niemiecką scenę polityczną jesienią 2011 r. Partia Piratów straciła rozmach w drugiej połowie 2012 r. Wśród Piratów co chwilę wybuchają różne skandale, partia odczuwa ciągłe trudności organizacyjne, przez co w sondażach spadła już do poziomu $3 \%$.

6) Stabilność koalicji - Do negatywnych skutków postępującej pluralizacji systemu partyjnego można zaliczyć znacznie większą trudność w powoływaniu stabilnych koalicji rządowych cieszących się zaufaniem ponad połowy parlamentu. Przypadki Kraju Saary i Nadrenii Północnej- 
-Westfalii pokazują, jak trudno jest utrzymać w ryzach rząd złożony z co najmniej trzech partii, bądź też liczyć na tolerancję innej partii dla rządu mniejszościowego. Doświadczenia z Kraju Saary i Nadrenii Północnej-Westfalii mogą mieć wpływ na kształt przyszłej koalicji na szczeblu federalnym.

7) Niemiecki system partyjny cały czas ewoluuje. Wydaje się, że w chwili obecnej stoi okrakiem nad przepaścią i waha się, w którą stronę się udać. Czy pójść dalej w stronę decentralizacji i większej pluralizacji, czy może powrócić do dominacji dwóch wielkich partii. Z perspektywy końca 2012 r. oba rozwiązania są możliwe. Za ok. 10 miesięcy poznamy przynajmniej część odpowiedzi. Na razie trudno jest powiedzieć ile partii dostanie się do Bundestagu w kolejnych wyborach, ani jakie koalicje powstaną.

\section{Zusammenfassung}

Die Bundestagswahl vom 27. September 2009 stellt einen wichtigen Wendepunkt in der Geschichte des deutschen Parteiensystems dar. Infolge der Wahl erlitten die Parteien der großen Koalition (CDU/CSU-SPD) Verluste, die besonders spürbar für SPD waren (-11,2 Prozentpunkten). Demgegenüber verbesserte sich die Lage der Oppositionsparteien: FDP, die Linke, die Grünen. Nach elf Jahren Pause kehrte die schwarz-gelbe Koalition (CDU/CSU-FDP) an die Macht zurück. Die Existenz eines Fünfparteiensystems in Deutschland wurde durch die Wahlen bestärkt. Das schwache Ergebnis der beiden großen Volksparteien (insgesamt 56,8\%) hat die Zweiparteiendominanz im deutschen Parteiensystem in Frage gestellt. In den Jahren 2010-12 zeigten die Wahlen und Meinungsumfragen, dass den beiden Volksparteien gelungen ist, ihre Position wiederherzustellen, währenddessen die Koalitionspartei FDP, welche am Rande der Sperrklausel balanciert, schmerzhafte Verluste erlitt. Dank der Debatte über die Zukunft der Atomenergie und den Protestbewegungen (Wutbürger, Stuttgart 21) an der Wende 2010/2011 stieg die Unterstützung für die Grünen, was sich im März 2011 während der Landtagswahl in Baden-Württemberg und Rheinland-Pfalz wiederspiegelte. Die Grünen erlitten bestimmte Verluste im Herbst 2011, als die Piratenpartei nach den Wahlen in Berlin ein enormes Erfolg erzielte. Die Piraten wurden zur sechsten Gruppierung, die eine Chance hat, in 2013 in den Bundestag zu kommen. 2012 stabilisierte sich die Situation auf der deutschen Parteienszene: am stärksten blieben CDU/CSU (über 35\% Unterstützung in Umfragen), danach SPD (ca. 30\%), an der dritten Stelle befanden sich die Grünen (13-15\%), und die drei weiteren Parteien - Die Linke, die Piratenpartei und FDP - balancierten am Rande der Sperrklausel (ca. 5\%). Dies alles zeigt, dass es zehn Monate vor der Wahl schwer vorhersehbar ist, wie viele Parteien in den Bundestag kommen werden, und welche Koalition nach den Wahlen entstehen wird. 